\title{
Development of Methodical Approach on Identification of Cluster Forms of the Organization of Economy of the Traditional and Agrarian Region
}

\author{
Irina Viktorovna Taranova ${ }^{1}$, Aleksandr Yur'yevich Gunko ${ }^{1}$, Oksana Anatol'evna Alekseeva ${ }^{2}$, Oleg Nikolaevich \\ Bunchikov $^{3} \&$ Viktoriya Vital'evna Kurennaya ${ }^{1}$ \\ ${ }^{1}$ FGBOU VPO "Stavropol State Agrarian University", Stavropol, Russian Federation \\ ${ }^{2}$ FGAOU VPO "North Caucasian Federal University", Stavropol, Russian Federation \\ ${ }^{3}$ FGBOU VPO "Don State Agrarian University”, Village Persianovsky, Russian Federation \\ Correspondence: Irina Viktorovna Taranova, FGBOU VPO "Stavropol State Agrarian University”, Mira Street, \\ 347, 355009, Stavropol, Russian Federation.
}

Received: November 20, 2014 Accepted: February 24, 2015 Online Published: May 22, 2015

doi:10.5539/ass.v11n14p95

URL: http://dx.doi.org/10.5539/ass.v11n14p95

\begin{abstract}
The spatial organization of economy of the Russian regions endures a certain crisis of the existing schemes of territorial localization and functioning of the leading sectors of economy and their enterprises. The accruing fragmentation of economic space and social and economic differentiation is a result of lack of effective counteraction to this crisis. Regions with agrarian orientated economy are more sensitive to processes of uneven development of economic space because they are more dependent on natural and geographical regularities, and the focused development of separate zones leads to synchronous formation of depressive territories with the low level of the key social and economic parameters, despite the available resource potential. Therefore, formation of new approaches to the organization of economic space of the agrarian oriented regions has to coordinate with identification of all leading sectors of economy, zone and polar forms of economic growth and leads to the introduction of different types of cluster innovations on the basis of stimulation of the relevant initiatives. Exactly potential of the cluster forms of the organization of economic space is capable to extend on extensive adjacent territories, forming network designs with the mode of active social and economic development.

According to this, an object of this research is development of theoretical and methodical provisions and conceptual approaches and recommendations about improvement of management of development of the agrarian oriented region on the basis of using cluster approach. As a result of the solution of the objective it is offered, based on selection and the analysis of quantitative indicators, methodical approach on identification of potential of clustering in the leading branches of economy of the agrarian oriented region. Also basic elements of the concept of management of the region on the basis of using cluster approach were specified with using the scenario of stage-by-stage development of a cluster in a key branch of economy and the scenario of a polybranch clustering of economy with creation of clusters in several leading branches.
\end{abstract}

Keywords: regional economy, clusters, regional management, potential of formation of a cluster

\section{Introduction}

Large-scale geopolitical, social and economic transformations in Russia and unstable, multidirectional nature of processes of regional economic dynamics define a need of searching original and innovative approaches to organise economic space at the level of subjects (Gerasimov, Gromov, \& Skripnichenko, 2014; Erlander, 1980).Specifics of spatial and economic regularities of development of the agrarian oriented regions as classification group of territorial subjects, define a need of the appeal to the potential of cluster forms of economic space organization. Further prospects of effective strategic management of the region on the basis of cluster approach substantially depend on a choice of a rational methodological basis of formation of the corresponding concept taking into account the leading branches which has a potential to format clusters. It has to consider not only priorities of a territorial order, but also social and economic aspects of activity of territories where problems of ensuring economic growth, maintenance of a worthy level of living of the population, development of infrastructure and others are particularly acute. The situation is complicated by inertial nature of 
post-crisis dynamics of development of agrarian sector of economy, which negative consequences might be redused or compensated with using new spatial and economic constractions (Trukhachev, Kostyukova, Gromov, \& Gerasimov, 2014; Garretsen \& Martin, 2010).

Multilateral development of theoretical aspects, methodical recommendations, and also organizational and economic approaches, methods, mechanisms and instruments of strategic management of the clustering in the agrarian oriented region will allow to increase quality of management of regional social and economic systems, to prepare its economic space for a macroeconomic setization with development of new properties and characteristics of its components.

\section{Methodology}

Basic and applied researches of domestic and foreign scientists in the field of the organization of economic space and the clustering of economy, program and strategic documents of regional planning, federal and regional regulations, reports, applied, instructive and reference materials on the problem of management of regional social and economic systems with use of potential of cluster approach, materials of scientific conferences and seminars, sources of encyclopedic character, thematic publications in periodicals formed a theoretical and methodological basis of research.

The research is executed on the basis of system approach application. Depending on objectives, methods of the analysis and synthesis, induction and deduction, receptions of the statistical, logical, semantic, retrospective, comparative and structural analysis, and also graphic, calculated and constructive, monographic, expert methods were used.

Information base of the research was formed by using official data of Federal State Statistics Service, its regional divisions, materials of departmental reports, and also results of monographic researches of domestic and foreign scientists. Information bases for a formulation of the main conclusions and recommendations of the research were subfederal empirical and factual data, and also the relevant information received by collecting, processing of representative data with the use of analytical and heuristic potential of the corresponding methods and receptions.

\section{Results}

\subsection{Statement of the Problem of Development of Methods for an Assessment of Clustering Potential}

Existing technological logic and branch approach of traditional industrial policy of the region need to be transformed and replaced with territorial and spatial. The development of effective system of the interconnected actions of federal, regional and municipal power institutes, which is focused on development of initiatives of power and enterprise structures with the purpose of realization of clear competitive advantages of the territory, has to be the main objective of the cluster policy (Hanson, 2005; Edwards, 2007).

Important task in the context of the research is developing such approach which would differentiate intrinsic aspects of identification of cluster capacity of the territory and already created cluster as a full-fledged institute of spatial economics. Talking about Stavropol region of Russian Federation, which is a model in the research, it is still difficult to speak about the created clusters, there are only some prerequisites of them and also the leading branches possess rather the clustering potential, than attributes of the created cluster. In this regard the developed methodology has to be focused on a comparison of potential of various sectors of regional economy from the point of clustering prospects.

There is a set of approaches to the identification of clusters in the modern theory and practice of regional economy:

1. Approach within the theory of competitive advantages of the territory (Head \& Mayer, 2004; Fujita, Krugman, \& Venables, 1999). It assumes an assessment the developed determinant of cluster development (local competitive advantages) and estimates the resource capacity of the territory, the characteristics of the related and serving branches, condition of demand for the made production, existence of common vision of development of the cluster and maintenance of the principles of the competition and cooperation.

2. Approach within the institutional theory (Capello, 2006; Ersoy \& Taylor, 2012). Prospects of formation of special institutes supporting effective interaction of all participants of a cluster and power structures are estimated within this approach.

3. Approach within the evolutionary theory. It assumes an identification of life cycle stages of a cluster, an assessment of an area of distribution of the cluster, in the context of studying of features of placement of productive forces, and also identification of small and innovative enterprise structures in the cluster. 
4. Approach "from top to down" assumes identification of a cluster by means of quantitative methods of the analysis of the tables "expenses-release". Usually, such approach is applied to already developed clusters.

5. Approach "from top to down" assumes identification of clusters on the basis of interviewing, questioning and other oral forms of research, so this is the qualitative analysis of a cluster which allows to reveal internal vertical and horizontal links between enterprises of the cluster.

6. Micro-level methods and methods of the interindustry cluster analysis. The tools of these methods are based on application of a method the main components and the factorial analysis, the multidimensional statistical cluster analysis, the theory of counts, etc.

Thus, all variety of the existing approaches to identification of clusters in regional economy is come down to use of a number of analytical tools (Bobryshev, Uryadova, Lyubenkova, Yakovenko, \& Alekseeva, 2014; Bobryshev, Golchenko, \& Kazakov, 2014). Application of each tool has both advantages and disadvantages. Examples of such tools:

- expert polls;

- calculation of special indicators (coefficients);

- data analysis of interindustry balance;

- network analysis.

We made a start from a hypothesis in the research that only the combination of several methods can lead to obtaining relevant information concerning clustering prospects in the region (Brakman, Garretsen, Gorter, Horst, \& Schramm, 2005; Baldwin, Forslid, Martin, Ottaviano, \& Robert-Nicoud, 2005). We will relate calculation of special indicators (coefficients) and informal (qualitative) analysis to such methods. Each of these approaches demands justification of indicators of clustering in a region, the only difference is that in the first case it will be quantitative indicators, and in the second - qualitative. It should be noticed that the methodology should not be "overloaded" with a large number of the low-informative and duplicated indicators. So such analysis should not be consolidated to statistical research of a huge number of data that will complicate unambiguous interpretation of the situation in the region which was occurred in the context of clustering prospects. Besides, an important methodical task is an integrated assessment of quantitative and qualitative parameters of functioning of leading branches in a region that finally will allow to interpret the received results linguistically.

\subsection{Development of the System of Indicators for a Quantitative Assessment of Clustering Potential}

Following logic of the research, we will move to the description of the selected quantitative indicators of clustering prospects in regional economy.

1. Production localization coefficient:

$$
\text { Кл }=\frac{\mathrm{Op}}{\Pi p} * 100 / \frac{\mathrm{Oc}}{\Pi \mathrm{c}} * 100,
$$

where $O_{p}$ - branch of the area;

$O_{c}$ - branch of the country;

$\Pi p$ - production total volume size in the region

$\Pi c$ - production total volume size in the country (GDP).

Calculating this indicator, we will use the size of a gross regional product as production total volume in the country and respectively for the country - GDP.

2. The coefficient on per capita production is calculated as the ratio the share of a branch of economy of the area in the relevant structure of the branch of the country to the share of the population of the region in the population of the country (Combes, Mayer, \& Thisse, 2009; Davis \& Weinstein, 1999):

$$
\mathrm{K}_{\mathrm{zm}}=\frac{\mathrm{Op}}{\mathrm{Hp}} * 100 / \frac{\mathrm{Oc}}{\mathrm{Hc}} * 100,
$$

where $H_{p}$ - economically active population of the region, thousand people

$H_{c}$ - economically active population of the country, thousand people. 
Thus, we used instead of the total number of the population of the region (country), the number of economically active population to calculate this indicator. This indicator, in fact, characterizes comparative productivity in the branch of the region and is quite relevant in the context of objectives of the developed methodology.

3. The coefficient of regional marketability is calculated as the ratio of export of goods from the territory to its regional production (Note 1):

$$
\mathrm{K}_{\mathrm{pT}}=\frac{\mathrm{Bc}}{\Pi p},
$$

where $\mathrm{Bc}$ - the volume of export of goods from the region;

$\Pi p$ - volume of production.

In case, if the actual value of the above-stated indicators exceeds 1, data of the branch can be considered as bases of market specialization of the region.

4. Ballas's index (index of the revealed comparative advantages (RCA)).

Proceeding from an assumption that one of the main identification signs of a cluster is that fact that the territory earns on export of the products, this indicator in the context of the research is rather informative. According to this index, the region can be identified as specializing on export of some product or service if its market share for this type of goods is higher, than an average value about the country:

$$
\operatorname{RCA}_{\mathrm{ij}}=\left(\left(\mathrm{x}_{\mathrm{ij}} \div \mathrm{X}_{\mathrm{i}}\right)\right) /\left(\mathrm{x}_{\mathrm{aj}} \div \mathrm{X}_{\mathrm{a}}\right)
$$

where, RCAij - coefficient of the revealed comparative advantages;

$\mathrm{xij}$ - export of a product $\mathrm{j}$ from the country $\mathrm{i}$;

$\mathrm{Xi}$ - total exports from the country $\mathrm{i}$;

$\mathrm{xaj}$ - total exports of a product $\mathrm{j}$ from the region $\mathrm{a}$;

$\mathrm{Xa}$ - total exports from the region $\mathrm{a}$.

In case, the region in a certain branch value of the indicator exceeds 1 , it means that export surpassed expectations on the basis of data on its demand in a total amount of export of this region.

5. Cluster focus (according to M. Porter) (Delgado, Porter, \& Stern, 2010) (S) is calculated as the ratio of quantity of occupied population in $\mathrm{i}$ sector in the region $\mathrm{j}$ to total amount of occupied population in the region $\mathrm{j}$ :

$$
\mathrm{S}=\mathrm{H}_{\mathrm{o}} / \mathrm{H}_{\mathrm{p}}
$$

where, $\mathrm{Ho}$ - the number of occupied population in i sector in the region $\mathrm{j}$;

$\mathrm{Hp},-$ the total number of occupied population in the region $\mathrm{j}$.

In fact this indicator is one of kinds of an indicator of localization. According to M. Porter it characterizes the amount of agglomeration, so when the value of the indicator is higher, then the agglomeration is bigger.

6. The density of economic space in sector $i$ of region. This indicator is the spatial characteristic of functioning of a potential cluster. It is calculated as the ratio of the enterprises of branch to territory size, so the number of the enterprises are located on 1 sq.km of the territory of the region is bigger, then the density of economic space is higher, respectively there are more than opportunities for interaction and cooperation.

7. The indicator of economic prosperity of a branch characterizes the ratio of a salary of a worker in the branch to an average annual salary in the region:

$$
\ni=3_{0} / 3_{p}
$$

where, 30 - The average monthly nominal salary of employees of organizations of the branch $i$ in the region $j$; $\mathrm{Hp},-$ the Average monthly nominal salary of employees of organizations in the region $\mathrm{j}$.

This indicator can be interpreted as if highly paid workplaces increase in a branch or they are more highly paid in the branch, than in other sectors of economy is observed, this branch can be considered as prospering.

\subsection{Results of the Computational Experiment}

We will use the following auxiliary data about branches of Stavropol region in 2013 to calculate the above described coefficients (Table 1). 
Table 1. Indicators for calculation of coefficients of localization in branches-carriers of clustering potential of Stavropol region (data for 2011)

\begin{tabular}{|c|c|c|c|}
\hline \multirow[b]{2}{*}{ Indicators } & \multicolumn{3}{|c|}{ Potential cluster-forming sectors } \\
\hline & $\begin{array}{l}\text { Tourism and } \\
\text { recreation }\end{array}$ & $\begin{array}{l}\text { Processing } \\
\text { productions }\end{array}$ & $\begin{array}{l}\text { Agricultural } \\
\text { industry }\end{array}$ \\
\hline $\begin{array}{l}\text { Average annual number of employed in the industry in Stavropol region, } \\
\text { thousand people }\end{array}$ & 24,9 & 146,4 & 216,7 \\
\hline $\begin{array}{l}\text { Average annual number of employed in the industry in Russia, thousand } \\
\text { people }\end{array}$ & 1217,6 & 10281 & 6730,4 \\
\hline Volume of industry production in the region, million rubles & 11728,1 & 161181 & 103470 \\
\hline Volume of industry production in Russia, million rubles & 373985,201 & 22802348 & 3261695 \\
\hline The branch cost of fixed assets in economy of the region, million rubles & - & 70614 & 87337 \\
\hline The branch cost of fixed assets in economy of Russia, million rubles & - & 8876602 & 3127209 \\
\hline $\begin{array}{l}\text { Export of main types of the made goods million rubles (the average US } \\
\text { dollar exchange rate for 2011) }\end{array}$ & 42 & 23862 & 7470 \\
\hline The average monthly nominal salary of employees of organizations & 10210 & 14685 & 12693 \\
\hline
\end{tabular}

Calculation will require some generalized data about economy of Stavropol region and the Russian Federation.

Table 2. The generalized data about economy of Stavropol region and the Russian Federation for calculation of indicators for an assessment of the clustering potential in the region

\begin{tabular}{lcc}
\hline Indicator & Russian Federation & Stavropol region \\
\hline Gross product, million rubles & 37398520,1 & 316888,9 \\
Total number of economically active population, thousand people & 75752 & 1373 \\
Total cost of fixed assets in economy, million rubles & 30736997 & 360357 \\
Average annual number of employed in the economy, thousand people & 67727,2 & 1245,3 \\
The average monthly nominal salary of employees of organizations & 23369,2 & 15588,7 \\
\hline
\end{tabular}

Generally, it should be noted that proceeding from the assessment of indicators of localization, 2 branches agricultural industry, that is a potential agro-industrial cluster and tourism and a recreation are allocated. The highest value of coefficient of localization on the number of the employed people is noted in agricultural industry $-1,78$ (Table 3 ).

Table 3. Calculation of indicators of localization in branches-carriers of the clustering potential

\begin{tabular}{|c|c|c|c|c|}
\hline \multirow{3}{*}{ № } & \multirow{3}{*}{ Indicators } & \multicolumn{3}{|c|}{ Potential cluster-forming sectors } \\
\hline & & $\begin{array}{l}\text { Tourism and } \\
\text { recreation }\end{array}$ & $\begin{array}{l}\text { Processing } \\
\text { productions }\end{array}$ & $\begin{array}{l}\text { Agricultural } \\
\text { industry }\end{array}$ \\
\hline & & \multicolumn{3}{|c|}{ Indicator value / place } \\
\hline 1 & $\begin{array}{c}\text { Localization coefficient of the volume of the made goods, works, } \\
\text { services }\end{array}$ & $\begin{array}{l}3,7010 \\
\text { II }\end{array}$ & $\begin{array}{c}0,8342 \\
\text { III }\end{array}$ & $\begin{array}{c}3,7439 \\
\text { I }\end{array}$ \\
\hline 2 & Localization coefficient of the number of the employed people & $\begin{array}{l}1,1282 \\
\text { II }\end{array}$ & $\begin{array}{l}0,7857 \\
\text { III }\end{array}$ & $\begin{array}{l}1,7764 \\
\text { I }\end{array}$ \\
\hline 3 & Localization coefficient of the cost of fixed assets & $\begin{array}{l}0,4342 \\
\text { III }\end{array}$ & $\begin{array}{l}0,6785 \\
\text { II }\end{array}$ & $\begin{array}{l}2,3822 \\
I\end{array}$ \\
\hline 4 & Coefficient of per capita production & $\begin{array}{l}1,7302 \\
\text { II }\end{array}$ & $\begin{array}{l}0,3999 \\
\text { III }\end{array}$ & $\begin{array}{l}1,7502 \\
I\end{array}$ \\
\hline 5 & Coefficient of regional merchantability & $\begin{array}{c}0,0036 \\
\text { III }\end{array}$ & $\begin{array}{l}0,1480 \\
\text { I }\end{array}$ & $\begin{array}{l}0,0722 \\
\text { II }\end{array}$ \\
\hline 6 & Index of the revealed comparative advantages (RCA) & $\begin{array}{l}0,0012 \\
\text { III }\end{array}$ & $\begin{array}{l}0,1854 \\
\text { I }\end{array}$ & $\begin{array}{l}0,1353 \\
\text { II }\end{array}$ \\
\hline 7 & Index of cluster focus & $\begin{array}{l}0,0200 \\
\text { III }\end{array}$ & $\begin{array}{l}0,1176 \\
\text { II }\end{array}$ & $\begin{array}{l}0,1740 \\
\text { I }\end{array}$ \\
\hline 8 & $\begin{array}{c}\text { Density of economic space in sector } \mathrm{i} \text { of the region (the enterprises on } \\
1 \text { thousand sq.km of the territory) }\end{array}$ & $\begin{array}{c}21,1 \\
\text { III }\end{array}$ & $\begin{array}{c}59,1 \\
\text { II }\end{array}$ & $\begin{array}{l}205,1 \\
\text { I }\end{array}$ \\
\hline 9 & Indicator of economic prosperity & $\begin{array}{l}0,6550 \\
\text { III }\end{array}$ & $\begin{array}{l}0,9420 \\
\text { I }\end{array}$ & $\begin{array}{l}0,8142 \\
\text { II }\end{array}$ \\
\hline 10 & Sum of places & 24 & 18 & 12 \\
\hline
\end{tabular}


The criteria indicator of the indicator of per capita production (1) is not exceeded only in sector of the processing productions $(0,399)$ while the maximum value of the coefficient of regional merchantability is in this branch. This fact confirms the value of the index of the revealed comparative advantages that maximum value is the share of the processing productions $(0,19)$, and practically all export potential of the branch is provided by chemical branch. The relation between the made goods and the exported goods is much lower in the sphere of agricultural industry.

The cluster focus indicator should be considered as one more clear indicator of strong economic incentive to the clustering processes. Proceeding from its value, the largest potential cluster in Stavropol region is the agricultural industry $(0,17)$. Thus the most dense economic space is observed in agricultural industry that also creates additional incentives for cooperation and more profound interaction $(205,1$ enterprises on 1 thousand sq.m of the territory).

Based on the indicator of economic prosperity of branch it is can be judged which type of economic activity provides highly paid workplaces and the extent of such providing that finally testifies to development of a potential cluster. From calculations we made, it is seen that none of the studied industries is more significant in comparison with regional average.

Generally, results of the research do not contradict data of similar works in this field (Gerasimov, Gromov, \& Levchenko, 2014; Gerasimov, Gromov, \& Levchenko, 2014; Bobryshev \& Kazakov, 2013).

\subsection{Total Interpretation of Results of the Quantitative Analysis}

It is necessary to range values of the calculated indicators of three industries in their size to interpret the data obtained as a result of the analysis. It will allow to apply the methodology of a complex rating assessment of separate types of economic activity in the context of clustering prospects by method of the sum of places. According to it, than less there will be a sum of places on concrete industry, then more perspective from the point of view of realization of cluster initiatives this industry is.

Considering that the methodology involved 9 indicators that were calculated for the three industries, the maximum sum of places will be equal to 27 , minimum is 9 . According to the accounting of allocation of three typological groups of industries, we will get the size of an interval step between each of them equal to 6 . Thus, as a result of the quantitative analysis of clustering prospects in the leading industries of Stavropol region the following results (Table 4) were received.

Table 4. Distribution of branches of Stavropol region on the typological groups characterizing prospects of clusters formation

\begin{tabular}{cccc}
\hline Typological group & Interval value & Branch of the region & Actual sum of places \\
\hline The biggest prospects of clustering & $9-15$ & Agricultural industry & 12 \\
Average prospects of clustering & $15-21$ & Processing productions & 18 \\
The least prospects of clustering & $21-27$ & Tourism and recreation & 24 \\
\hline
\end{tabular}

\subsection{Development of a System of Indicators for the Qualitative Assessment of Clustering Potential}

This methodology would be not complete if we made the quantitative assessment of prospects of clustering because the process of the comparative analysis of different branches is not objective enough. Finally imposed results of the quantitative analysis on results qualitative, we will be able to estimate clustering prospects in the leading sectors of economy of Stavropol region fully.

These criteria were estimated in the expert path, as a result of poll of representatives of the science and power structures of the region, focus group. Based on the offered system of qualitative indicators, each of experts estimated 3 sectors of economy of Stavropol region regarding clustering prospects. We interrogated 20 experts in total. Each of them ranged branches regarding compliance to qualitative parameters therefore the matrix of points according to qualitative indicators of clustering prospects (Table 5) was made.

Questions for experts were formulated so that each expert estimated criterion according to a scale of the standard importance from 1 to 3 points where are 1 the best position of branch in aspect of clustering, 3 - the worst. Thus the expert could put to several branches an equal number of points as to estimate some aspects of clustering is rather difficult, without being the expert in this branch, at the same time, when the expert is sure that by this criterion the branch is the most perspective, he/she can put to it 1 point, and to other branches - 3 points. Than the number of points is less, then clustering prospects in this branch are higher. 
Table 5. Results of clustering prospects in industries of Stavropol region based on the expert poll

\begin{tabular}{|c|c|c|c|}
\hline \multirow[t]{2}{*}{ The qualitative assessment criteria } & $\begin{array}{c}\text { Tourism and } \\
\text { recreation }\end{array}$ & $\begin{array}{l}\text { Processing } \\
\text { productions }\end{array}$ & $\begin{array}{l}\text { Agricultural } \\
\text { industry }\end{array}$ \\
\hline & \multicolumn{3}{|c|}{ Experts points } \\
\hline $\begin{array}{l}\text { 1. Existence of the industry's "core cluster" or pronounced leaders around } \\
\text { which the cluster formation may occur in the future }\end{array}$ & 54 & 29 & 49 \\
\hline $\begin{array}{l}\text { Extent of development of intra-industry integration based on the principles } \\
\text { of competition and cooperation }\end{array}$ & 22 & 37 & 52 \\
\hline 3. Image of a branch & 36 & 49 & 28 \\
\hline 4. Existence of uniform strategy & 28 & 44 & 52 \\
\hline $\begin{array}{l}\text { 5. In which branch an approach to increase of competitiveness of production } \\
\text { is most applied }\end{array}$ & 39 & 53 & 47 \\
\hline $\begin{array}{l}\text { 6. In which branch the competition among suppliers of raw materials, the } \\
\text { materials completing and others is higher }\end{array}$ & 58 & 47 & 38 \\
\hline $\begin{array}{l}\text { 7. Which industry has developed more sustainable chain of enterprises } \\
\text { operating on the principles of cooperation }\end{array}$ & 31 & 53 & 42 \\
\hline 8. In which branch the role of the serving and supporting sectors is higher & 24 & 46 & 28 \\
\hline $\begin{array}{l}\text { 9. Consumers' impact on the competitiveness of made products, services } \\
\text { (quality demand, it means that consumers in which industry are more } \\
\text { demanding) }\end{array}$ & 24 & 45 & 33 \\
\hline $\begin{array}{l}\text { 10. Influence of the state on branch (a positive role from the point of } \\
\text { clustering prospects) }\end{array}$ & 22 & 41 & 28 \\
\hline $\begin{array}{l}\text { 11. In which branch influence of negative random events on development of } \\
\text { clusters is lower ( } 1 \text { - the lowest influence, } 3 \text { - the highest influence) }\end{array}$ & 34 & 27 & 38 \\
\hline 12. The similarity of resource use between large groups of enterprises & 41 & 36 & 22 \\
\hline $\begin{array}{l}\text { 13. The closeness of connections in the sector on the labour market and } \\
\text { goods ( } 1 \text { is the most close, } 3 \text { - least close) }\end{array}$ & 36 & 42 & 38 \\
\hline $\begin{array}{l}\text { 14. Prospects of increase in number of large (significant) participants of a } \\
\text { potential cluster ( } 1 \text { - the greatest prospects of expansion; } 3 \text { - the smallest) }\end{array}$ & 38 & 52 & 24 \\
\hline 15. The prospects for increasing the export potential & 58 & 25 & 33 \\
\hline $\begin{array}{l}\text { 16. The role of branch in formation the general brand of the region ( } 1 \text { - } \\
\text { highest, } 3 \text { - lowest) }\end{array}$ & 31 & 56 & 30 \\
\hline $\begin{array}{l}\text { 17. Prospects of expansion of the range of products and deepening of system } \\
\text { of labor division }\end{array}$ & 41 & 53 & 34 \\
\hline 18. Prospects of copying and introduction of advanced technologies & 24 & 35 & 46 \\
\hline 19. Activity of sector in exhibition activity & 33 & 51 & 25 \\
\hline $\begin{array}{l}\text { 20. The leading role of the sector in the integration around a large number of } \\
\text { subjects of small business }\end{array}$ & 27 & 34 & 48 \\
\hline Total amount of points & 701 & 855 & 735 \\
\hline
\end{tabular}

As a result of the conducted expert survey sectors of economy of Stavropol region were divided on typological groups as follows (Table 6).

Table 6. Distribution of branches of the Stavropol region on typological groups, characterizing the formation of clusters according to the results of the qualitative assessment

\begin{tabular}{|c|c|c|c|}
\hline Typological group & Interval sum of points & Branch of the region & Actual sum of points \\
\hline $\begin{array}{l}\text { The biggest prospects of } \\
\text { clustering }\end{array}$ & $267-534$ & no & - \\
\hline $\begin{array}{l}\text { Average prospects of } \\
\text { clustering }\end{array}$ & $534-801$ & $\begin{array}{l}\text { Tourism and retail trade } \\
\text { Agricultural industry }\end{array}$ & $\begin{array}{l}701 \\
735\end{array}$ \\
\hline $\begin{array}{c}\text { The smallest prospects of } \\
\text { clustering }\end{array}$ & $801-1068$ & $\begin{array}{l}\text { Service industry (chemical and } \\
\text { petrochemical industry) }\end{array}$ & 855 \\
\hline
\end{tabular}

\subsection{Discussion}

As a result, we imposed the results of the quantitative and qualitative assessment of the prospects of the cluster formation in the leading sectors of Stavropol region and gave their characteristics (Table 7). It allowed us to estimate the clustering prospects in three basic branches of Stavropol region. 
Table 7. Characteristic of potential clusters of Stavropol region

\begin{tabular}{|c|c|c|c|c|c|c|}
\hline \multirow{3}{*}{$\begin{array}{l}\text { Feature } \\
\begin{array}{l}\text { Clustering prospects according to methodology of } \\
\text { the quantitative assessment }\end{array}\end{array}$} & \multicolumn{6}{|c|}{ Sector of potential clustering } \\
\hline & \multicolumn{2}{|c|}{$\begin{array}{l}\text { Tourism and } \\
\text { Recreation }\end{array}$} & \multicolumn{2}{|c|}{$\begin{array}{l}\text { Processing } \\
\text { Productions } \\
\end{array}$} & \multicolumn{2}{|c|}{$\begin{array}{l}\text { Agricultural } \\
\text { Industry }\end{array}$} \\
\hline & The lowest & 24 & Average & 18 & The highest & 12 \\
\hline $\begin{array}{l}\text { Clustering prospects according to methodology of } \\
\text { the qualitative assessment }\end{array}$ & Average & 701 & The lowest & 855 & Average & 735 \\
\hline
\end{tabular}

As a result, we allocated the following:

(1). Tourist and recreational cluster is characterized by the following features: the nuclear-free cluster of tourist and recreational type that has unique natural and resource base and had already formed a well-known brand that is extrapolated to the entire territory. The limiting factor is a small influence and a low localization in relation to the regional economy. It provides significant incentives for the development of supporting and accompanying branches of the local economy particularly for small businesses, but its export potential is low. Its more effective development is possible to reach by using interregional interaction and creation of a cluster of higher order.

(2). The cluster of industrial and production type in the sphere of chemical and petrochemical production. In separate branches of this cluster the leading enterprises ("a cluster core") are clearly looked through, but extent of integration round them is low. It is the main carrier of the export potential of the entire regional, social and economic system. The cluster is capable to function without intervention from the state in its development, but its share in structure of the regional economy is small. It is not the system-forming cluster from the point of an employment and its role for the local economy is low, in order to position branch as a full-fledged cluster. An important prospect of further development is deepening of integration communications with adjacent sectors of economy. Serving production can become a link between several clusters in the region.

(3). The agricultural cluster. It is the production nuclear-free cluster that plays an important social and economic role for development of the local economy. The weakest characteristic features are insufficient for full development of the cluster internal communications between the companies that is shown in the absence of an optimal balance of "trust", "competition" and, especially, "cooperation". It is characterized with the high density of economic space and sufficient extent of localization, but it's innovative and export potential is weak. Further development is connected with the influence of uncontrollable factors in many respects. It is highly influenced by the state as the system-forming sector in the region.

\section{Conclusion}

The research on strategic management problems of the clustering of economy of the agrarian oriented region showed that, despite their importance for the economy of the region in general, questions of clusters formation have the fragmentary methodical base, which does not meet the requirements and imperatives of a post-industrial paradigm of development.

Currently, there are many unresolved questions that remain in a system of scientific support processes of clustering of economy. On the basis of the conducted research it is possible to make a number of the theoretical and practical conclusions and suggestions, answering a part of them. During the research there was established a need to identify opportunities and prerequisites of clustering with further justification of administrative decisions on spatial localization of clusters in a system of the territorial organization of economy. Thus the hypothesis was made according to which in the agrarian oriented region, besides agricultural branch, it is necessary to carry out a search of other propulsive sectors of economy to create a full-fledged multi-profile cluster structure. For these purposes we developed the methodological support for detection of prerequisites of clustering in propulsive sectors of economy including not only the analysis of quantitative indicators, but also attributive criteria. Results of its use with regard to empirical and factual material of Stavropol region as a typical representative of agrarian oriented regions showed that branches of agricultural industry, tourism and recreation and processing productions (industry) possess the greatest prospects of clustering.

\section{References}

Baldwin, R., Forslid, R., Martin, R., Ottaviano, G., \& Robert-Nicoud, F. (2005). Economic Geography and Public Policy. Princeton University Press.

Bobryshev, A. N., \& Kazakov, M. J. (2013). Rating territorial uneven development of economic entities 
traditionally agricultural regions. The collection includes material reports 3rd International Scientific and Practical Conference "Science and Society" held SCIEURO in London 20-21 March 2013 (pp. 137-157).

Bobryshev, A. N., Golchenko, Y. V., \& Kazakov, M. Y. (2014). Directions of municipal territorial and economic transformation in a monopolar highly urbanized region. Actual Problems of Economics, 2(152), 230-238.

Bobryshev, A. N., Uryadova, T. N., Lyubenkova, E. P., Yakovenko, V. S., \& Alekseeva, O. A. Analytical and management approaches to modeling of the accounting balance sheet. Life Sci J., 11(8), 502-506. Retrieved from http://www.lifesciencesite.com

Brakman, S., Garretsen, H., Gorter, J., van der Horst, A., \& Schramm, M. (2005). New Economic Geography, Empirics and Regional Policy. The Hague: Netherlands Bureau for Economic Policy Analysis.

Capello, R. (2006). Regional Economics (p. 316).

Combes, P. P., Mayer, T., \& Thisse, J.-F. (2009). Economic Geography: The Integration of Regions and Nations.

Davis, D. R., \& Weinstein, D. E. (1999). Economic geography and regional production structure: An empirical investigation. European Economic Review, 43, 379-407. http://dx.doi.org/10.1016/S0014-2921(98)00063-4

Delgado, M., Porter, M. E., \& Stern, S. (2010). Clusters and Entrepreneurship. Journal of Economic Geography, 1-24. http://dx.doi.org/10.1093/jeg/lbq010

Edwards, M. E. (2007). Regional and Urban Economics and Economic Development: Theory and Methods.

Erlander, S. (1980). Optimal Spatial Interaction and the Gravity Model: Lecture Notes in Economics and Mathematical Systems (N. 173, p. 120). Berlin, Heidelberg, N.Y.: Sprinder-Verlag. http://dx.doi.org/10. 1007/978-3-642-45515-5

Ersoy, A., \& Taylor, M. (2012). Understanding dynamics of local and regional economic development in emerging economies. Ekonomska istrazivanja-economic research, 1079-1088.

Fujita, M., Krugman, P., \& Venables, A. J. (1999). The Spatial Economy: Cities, Regions, and International Trade (p. 367). MIT Press, Cambridge (Mass.)-London (England).

Garretsen, H., \& Martin, R. (2010). Rethinking (New) Economic Geography Models: Taking Geography and History More Seriously. Spatial Economic Analysis, 5(2), 127-160. http://dx.doi.org/10.1080/1742177 1003730729

Gerasimov, A. N., Gromov, E. I., \& Skripnichenko, Y. S. (2014). Development of localized in space economies in traditionally agricultural regions of Russian Federation. Actual Problems of Economics, 156(6), 264-276.

Gerasimov, A. N., Gromov, Y. I., Levchenko, S. A., Grigorieva, O. P., \& Oboturova, N. P. (2014). Features of the spatial socio-economic systems development in the North Caucasus Federal District. World Applied Sciences Journal, 29(5), 699-705. http://dx.doi.org/10.5829/idosi.wasj.2014.29.05.13906

Gerasimov, A. N., Gromov, Y. I., Levchenko, S. A., Skrebtsova, T. V., \& Kobozev, M. A. (2013). Modeling and forecasting of key indicators of socio-economic development of traditionally agrarian regions. World Applied Sciences Journal, 27(10), 1282-1287. http://dx.doi.org/10.5829/idosi.wasj.2013.27.10.13740

Hanson, G. (2006). Market Potential, Increasing Returns, and Economic Concentration. Journal of International Economics, 67, 1-23. http://dx.doi.org/10.1016/j.jinteco.2004.09.008

Head, K., \& Mayer, T. (2004). The empirics of agglomeration and trade, The Handbook of Regional and Urban Economics, 4, 2609-2669. http://dx.doi.org/10.1016/S1574-0080(04)80016-6

Trukhachev, V. I., Kostyukova, E. I., Gromov, E. I., \& Gerasimov, A. N. (2014). Comprehensive socio-ecological and economic assessment of the status and development of Southern Russia agricultural regions. Life Science Journal, 11(5), 478-482.

Note

Note 1. Regional economy: the textbook for higher education institutions / Under the editorship of Morozova. - 3rd prod., reslave. and additional - M.: UNITY, 2004.

\section{Copyrights}

Copyright for this article is retained by the author(s), with first publication rights granted to the journal.

This is an open-access article distributed under the terms and conditions of the Creative Commons Attribution license (http://creativecommons.org/licenses/by/3.0/). 